\title{
Reject and Eject: Arresting the Vanishing Relevance of Non-refoulement Obligations in the United Kingdom
}

\section{Cosmas Ukachukwu Ikegwuruka}

Almond Legals-Immigration, Asylum and Human Rights Lawyers \& Researchers, London, UK

\section{Email address:}

almondlegals@yahoo.co.uk

\section{To cite this article:}

Cosmas Ukachukwu Ikegwuruka. Reject and Eject: Arresting the Vanishing Relevance of Non-refoulement Obligations in the United Kingdom. International Journal of Law and Society. Special Issue: Immigration Control, Citizenship, the Interplay of Sovereignty and the Vicissitudes of the Hostile Environment. Vol. 3, No. 1, 2020, pp. 20-31. doi: 10.11648/j.ijls.20200301.14

Received: February 13, 2020; Accepted: March 11, 2020; Published: May 12, 2020

\begin{abstract}
This paper argues that expulsion decisions in the United Kingdom are sometimes at variance with the very important non-refoulement obligations in international law and raises fundamental issues of concern. However, recent legal developments in the Strasbourg jurisprudence and the Court of Justice of the European Union seem to halt this trend of the vanishing relevance of non-refoulement obligations-a Daniel has come to judgment. This paper, applying the documentary analysis methodology argues that except this nascent development is maintained and sustained, non-refoulement obligations may still remain 'theoretical and illusory rather than practical and effective'. The bottom line is that a State is not excused from its human rights obligations by transferring, returning or removing a migrant to another State even on the basis of agreement without actually determining whether there will be violations of the individual's rights under international refugee law or international human rights law. It has therefore been shown that there is overwhelming evidence pointing to the establishment of non-refoulement as a norm of customary international law with wide acceptance by the international community of the prohibition of torture and cruel, inhuman and degrading treatment, as jus cogens.
\end{abstract}

Keywords: Immigration, Expulsion, Deportation, Non-refoulement, Medical Cases, International Law, Jus Cogens

\section{Introduction}

It is trite to say that States under well-established principles of international law have the right to control the ingress and egress of non-nationals into its territory'[1] enjoying as it had over time, the exercise of discretion to exclude such non-nationals as the State may deem necessary [2]. In essence, the power to expel flows from the State's exercise of sovereignty given that the grounds for expulsion (deportation and/or removal) of migrants may be determined solely by the State but subject to its treaty obligations. Therefore, the legitimacy of expulsion is measured by the State's adherence to domestic and international human rights norm such as prohibition against refoulement [3]. Lauterpacht and Bethlehem argue that the principle of nonrefoulement has acquired the status of customary international law and noted that the customary status of both the prohibition of torture and of cruel, inhuman or degrading treatment or punishment is clear [4].

As it is, the right not to be tortured or subjected to inhuman or degrading treatment is an unqualified right that can never be balanced against competing considerations. Art 3 of the Convention Against Torture and Other Cruel, Inhuman or Degrading punishment (CAT) expressly prohibit States from removing an individual in a manner where there are substantial grounds for believing that he/she will be in danger of being subjected to torture (non-refoulement) [5]. Simply put, the prohibition against torture is a jus cogens-a binding obligation in international law [6].

This paper argues that expulsion decisions in the United Kingdom are sometimes at variance with the very important non-refoulement obligations in international law and raises fundamental issues of concern. However, recent legal developments in the Strasbourg jurisprudence and the Court of Justice of the European Union seem to halt this trend of the vanishing relevance of non-refoulement obligations-a Daniel has come to judgment. It is submitted that except this nascent development is maintained and sustained, non-refoulement obligations may still remain 'theoretical and illusory rather than practical and effective'. The sustenance of this nascent 
development will depend on further juridical developments as it concerns medical conditions of non-nationals facing expulsion in the United Kingdom at the time of this writing.

\section{Non-refoulement as Jus Cogens}

Non-refoulement, which simply means 'forbidding to send back', was noted to have appeared first as a requirement in history in the work of international societies of lawyers, at the 1892 Geneva Session of the Institute de Droit International (Institute of International Law) [7]. Article 16 of the 1892 Regles internationals sur l'admission et 'expulsion des etrangers stipulated that a refugee, should not by way of expulsion, be sent back to another state that sought him except under certain observed stipulated conditions [8]. As time went by, especially with the tensions generated during the two world war periods, the principle of non-refoulement started appearing explicitly in predominant number of international conventions, reemphasizing that refugees must not be returned to their countries of origin, with the United Nations giving vent to the consolidation of this principle in international law [7]. This became universal by virtue of Article 45 of the 1949 Geneva Convention relative to the Protection of Civilians Persons in Time of War which provided that 'in no circumstances shall a protected person be transferred to a country where he or she may have a reason to fear persecution for his or her political opinions or religious beliefs'. This later metamorphosed into the grant of broader rights by the application of Article 33 of the 1951 Geneva Convention relating to the Status of Refugees that stipulates:

1. No Contracting State shall expel or return ("refouler") a refugee in any manner whatsoever to the frontiers of territories where his life or freedom would be threatened on account of his race, religion, nationality, member- ship of a particular social group or political opinion.

2. The benefit of the present provision may not, however, be claimed by a refugee whom there are reasonable grounds for regarding as a danger to the security of the country in which he is, or who, having been convicted by a final judgment of a particularly serious crime, constitutes a danger to the community of that country [9].

In addition, with the development of international protection of human rights, the application of non refoulement was further enlarged as it grew beyond the framework of refugee law exemplified by international legal instruments, as can be inferred from the 1966 International Covenant on Civil and Political Rights (ICCPR), Article 7 which prohibits a person from being transferred to where they would be subjected to torture, or subjected to cruel, inhuman or degrading treatment or punishment [10]. In essence, the principle of non-refoulement is considered to be international customary law, implying that all states regardless of being parties to the applicable human rights and/or refugee conventions, which prohibit refoulement, are required not to return a person to a country where the person's life will be in danger [11]. As Duffy recounted, nonrefoulement having been accepted by 90 percent of world's sovereign state in some shape or form shows its normative worth and 'the incorporation of this principle into key international instruments is also testament to consistent practice and a strong opinion juris which contributes to the creation of a customary norm' [11]. In this connection, the Office of United Nations High Commissioner for Refugees opines that regardless of the exception in Article 33 (2) of the Refugee Convention 1951, the principle of non-refoulement has become a rule of customary international law based on state practice on the one hand and states' opinion juris on the other hand [12].

Having briefly examined the customary basis of the norm of non-refoulement, I will now move to the question of whether this customary norm is recognised as jus cogens, if so, what are the implications? I will quickly proceed by saying that the notion of jus cogens came into the lexicon of international law through the 1969 Vienna Conventions of the Law of Treaties, Articles 53 and 64. These provide for the termination or invalidation of treaties even after ratification if their content does conflict with a peremptory norm of general international law, 'accepted and recognised by the international community of States as a whole as a norm from which no derogation is permitted' [13]. As Allain pointed out, the international community had determined two types of laws that regulate their behavior namely jus cogens and jus dispositivum, where jus dispositivum are laws which States may derogate or deviate from while jus cogens do not allow for such deviations as they are higher norms which do not permit violation [14]. In essence, 'peremptory norms limit the actions and interactions of States on the international plane' [14].

That said, the question worth examining is how to identify the norms of jus cogens and whether the prohibition against refoulement meets those standards. To this end, several scholars have argued that non-refoulement is indeed jus cogens. Allain expresses the view that a jus cogens is identifiable where there is sufficient state practice and if the rule is recognised by opinion juris not only as custom but also as jus cogens [15]. In reaching this conclusion, he relied on the 1982 Executive Committee Conclusions, which observed that non-refoulement was 'progressively acquiring the character of a peremptory rule of international law'. Allain [14] treats non-derogability and jus cogens as functional equivalent, this, has been challenged by Castello and Foster as incorrect as a matter of law [16]. They argued that "while non-derogability is one of the formal indicia of a jus cogens norm (along with universality and peremptory character) that in itself is not sufficient' [16]. They pointed out that the statement that non-refoulement is non-derogable is an integral part of its acknowledgment as jus cogens but not total in conferring that character on a norm [16]. Orakhelashvili sees non-refoulement as jus cogens from the point of view of Art 33 of the 1951 Geneva Convention of the Status of Refugees stated above which according to him is a peremptory norm related to right of an individual, 
supported by its inseparable link with certain freedoms-right to life and freedom from torture, stating that the EXCOM Conclusion No. 25 attests that the principle of nonrefoulement amounts to a norm of jus cogens [17].

Farmer on his part expresses that 'whereas nonrefoulement has gained broad acceptance as a fundamental norm of refugee law, its exceptions have not garnered similar status' [18]. His thesis is that even though there is an exception in refugee treaties, no exceptions are found in Convention Against Torture (CAT), the ICCPR and the ECHR which protects individuals from refoulement in cases of torture or cruel, inhuman or degrading treatment [19]. For him, public order does not necessarily require the existence of a fixed, exhaustive catalogue of jus cogens, or peremptory norms, rather, certain criteria exist to identify these norms which the international community as a whole accept as norms which permit no derogation [18].

In addition, some regional and domestic orders treat nonrefoulement as jus cogens, such as the Cartagena Declarations on Refugees [19], the Organization for African Unity Convention [20] and quite recently the Brazil Declaration of December 2014 for Latin American and Caribbean governments [21], in addition to the dictum of Judge Pinto de Albuquerque in Hirsi Jamaa and Others $v$ Italy where he stated that 'the prohibition of refoulement is a principle of customary international law, binding on all States, even those not party to the UN Refugee Convention or any other treaty for the protection of refugees [...]' that permits no derogation due to its peremptory nature which disallows reservations [22].

Regardless of the above position treating non-refoulement as jus cogens, some scholars doubted the conclusion without critical examination. Duffy treats non-refoulement as custom but argues that evidence about its jus cogens status is less convincing [11]. Wouters does not accept that nonrefoulement in general is jus cogens, but accepts that the prohibition against torture does have the character of jus cogens [23]. Having reviewed the various positions, Castello and Foster, applying their 'customary international law plus' analysis take the view that non-refoulement is ripe for recognition as jus cogens on the basis that practice and opinio juris demonstrate its virtually universal scope and non derogability is evident in the language of relevant UN General Assembly resolutions [24]. As Lauterpacht and Bethlehem stated, 'non-refoulement is expressly protected in standard setting conventions that are concerned with extradition in addition to widespread and representative participation in the conventions said to embody the putative customary law' [25].

In the light of the above analysis, there is overwhelming evidence pointing to the establishment of non-refoulement as a norm of customary international law with wide acceptance by the international community of the prohibition of torture and cruel, inhuman and degrading treatment, as jus cogens.

\subsection{Non-refoulement and Human Rights Law}

Neuman thinks of non-refoulement as a rule concerning
State responsibility where States must refrain from refoulement in order to avoid complicity in serious human rights violation committed by others. He asserted that 'a state that knowingly (or with awareness of sufficient risk) compels an individual to return to a country where their rights will be violated is not merely neglecting to protect them but helps in causing the violation. This approach emphasizes the active character of refoulement' [27]. As Lehman [26] also observed in the case of Saadi v Italy [27] 'non-refoulement obligations are applicable where the return of an individual to a territory where he would be at risk of subjection to treatment that falls within the ambit of the principle and where such treatment is attributable to the State'. After the decision in Saadi v Italy [28], Strasbourg's jurisprudence in $A$ $v$ Netherlands [29] and $N v$ Sweden [30] amongst others had consistently re-emphasized the absolute nature of nonrefoulement. In view of the above and consistent with the recommendations of the Committee Against Torture, the UK government had accepted that the government would not remove a person under immigration powers where this would lead to treatment contrary to Art 3 CAT or Art 3 ECHR, while assuring that all removals may be appealable to the UK courts [31]. This assurance by the UK to the CAT, evidence suggests, appears to be at variance with UK's State practice in deportation and removal as will be discussed subsequently in this paper.

The provision against torture, cruel, inhuman or degrading treatment is also contained in Art 7 ICCPR [32]. In Lehman's view, 'although the prohibition of expulsion in the ICCPR is confined to aliens lawfully on the territory, the HRC has not excluded that in theory any right of the Covenant may lead to a non-refoulement obligation for any individual within the state's jurisdiction' [26]. In A. R. Jv Australia [33], the HRC stated that 'if a State party deports a person within its territory and subject to its jurisdiction in such circumstances that as a result, there is a real risk that his or her rights under the Covenant will be violated in another jurisdiction, that State party itself may be in violation of the Covenant' [32].

As stated supra, Art 3 ECHR prohibits torture, and inhuman or degrading treatment or punishment. Torture is not specifically defined in the ECHR but implies a deliberate infliction of suffering of particular intensity and cruelty [34]. In essence, the ECHR as a living instrument applies the purposive approach in interpreting Art 3 rights to the extent that what was classified as inhuman treatment could now be classified as torture in the light of the rising protection of human rights and fundamental freedoms [34]. In Tyrer $v$ UK [35] the ECtHR concluded that the judicial corporal punishment inflicted on the applicant amounted to degrading punishment within the meaning of Article 3 (art. 3) of the Convention'. As Rohl observed, 'because of its absolute protection against inhuman treatment "whatever the source" Article 3 ECHR considerably widens the international protection against refoulement compared to other refugee law and human rights instruments' [36].

By and large, Art 3 ECHR is an absolute right that cannot be balanced with competing considerations neither does it 
permit derogations under any circumstance. As the ECtHR stated, Art 3 'enshrines one of the fundamental values of democratic societies, prohibits in absolute terms torture, or inhuman or degrading treatment or punishment irrespective of the victim's conduct' [37]. However, in Soering $v$ UK [38] the ECtHR remarked that "what amounts to "inhuman or degrading treatment or punishment" depends on all the circumstances of the case'. The Soering case attracted a lot of commentaries where majority are in agreement with the ratio while others think otherwise. Mole observes [39] that for Art 3 ECHR to be engaged, 'it must be shown that the applicant is at risk of treatment prohibited by that article and such a risk must be real and would involve a determination of what is risked and the necessary threshold of severity must be met' [40].

In essence, inherent in the whole of the Convention is a search for a fair balance between the demands of the general interest of the community and the requirements of the protection of the individual's fundamental rights' [40]. The second part of this statement "a fair balance between the demands of the general interest of the community [...]" may appear to suggest a kind of balance to be struck between competing interests, which would have removed the absolute nature of Art 3, but the ECtHR was quick to explain it in subsequent paragraphs and specifically in Chahal when it emphasized that there is no room for balancing the risk of ill treatment against reasons for expulsion in order to determine whether a State's responsibility under Art 3 is engaged [41].

As MacDonald and Toal pointed out, the UK as a third party intervener in Saadi $v$ Italy [28, 34, 42] attempted unsuccessfully to persuade the ECtHR to revisit the Chahal principle stated supra, arguing that the government should be able to balance the risk to the individual consequent on removal against the gravity of the threat posed by that individual to the community [34]. But the argument did not find favour with the Court as it reaffirmed that the principles afforded by Art 3 was absolute given that 'the concepts of "risk" and "dangerousness" in this context do not lend themselves to a balancing test because they are notions that can only be assessed independently of each other' meaning that the conduct of the individual however undesirable or dangerous could not be taken into account [34]. The examination of this right for the purposes of this paper will be with respect to concept of so-called safe country, nonrefoulement and medical cases and torture in the country of destination.

\subsection{The Concept of Safe Country in Relation to Non-refoulement}

Having examined non-refoulement as jus cogens in the previous part, 'safe country' notion will now be briefly discussed. The notion of safe country has been explained as 'a procedural mechanism for shuttling asylum seekers to other States said to have primary responsibility for them, thereby avoiding the necessity to make a decision on the merits because another country is deemed to be secure' [43]. Simply stated, the concept of 'safe country' was an invention aimed at returning asylum seekers back to where they came from on the ground that they have already found protection or there will be protection in that country which is deemed safe. The fundamental question which is being engaged is whether the application of the notion of 'safe country' violates the principle of non-refoulement, which means, whether there is effective or adequate protection in the so called 'safe' country both as matter of law and State practice [43].

Foster refers to 'safe country' as 'protection elsewhere policy'- 'a situation in which a State or agency acts on the basis that the protection needs of a refugee should be considered other than in the territory of the State where the refugee has sought or intends to seek protection' [44]. These have been described with different labels notably 'country of first asylum', 'third safe country' 'safe country of origin' (an integral part of eligibility procedure in Europe) but the core question is to ensure protection and whether the State deviates or deflects from its obligation by transferring a refugee to another State [45], within the objective concept of protection against expulsion [46].

Gil-Bazo expressed that 'the most sophisticated mechanism developed by States to embody the 'safe third country' notion is currently contained in the so-called Dublin III Regulation of the European Union (EU)- a third generation instrument aimed at determining the EU Member State responsible to examine an asylum application on behalf of all other EU Member States'. Gil-Bazo [47] opined that as much as many scholars have focused on the issue of effective protection explicit in the discussion of the notion of 'safe third country', many have not queried its lawfulness, given that asylum is not discretionary but a right under international law. Gil-Bazo [47] had argued that 'the status of refugees under international law is defined [...] by the interaction of the different legal orders that may be applicable to any refugee in any given circumstances, both of universal and regional scope'. [47] remarked that when a State transfers responsibility to another State, even by the acceptance or admission that the receiving State is a 'safe third country' this raises crucial issues of state responsibility regarding the fulfilment of all obligations under the regime of both international refugee law and human rights law with respect to the exercise of jurisdiction [47]. In this context, prior to the determination of asylum claim, a Member State must verify the existence of a safe country which the applicant may be returned, which follows that the principle of the responsible state has been turned upside down to the extent that expulsion to a third state is no longer the exception but the rule [48].

In the United Kingdom, safe third country provisions are found in Schedule 3 of the Asylum and Immigration (Treatment of Claimants, etc.) Act 2004 that maintains an 'active' list of 28 countries of the European Economic Area (EEA) with the exception of Liechenstein' [49]. By virtue of this provision, which refers to section 77 (4) of the Nationality, Immigration and Asylum Act 2002, countries are deemed safe on Refugee Convention grounds-Articles 1 (A) 
2 and 33 or on human rights grounds- Articles 3 and 8 ECHR emphasizing that anyone who falls to be returned to an European country, may not appeal against the decision unless the Secretary of State is persuaded that such a decision, would arguably be, a breach of human rights by the UK in doing so.

The 'safe third country' and 'country of first asylum' owe its background to the Executive Committee of the High Commissioner's Programme (EXCOM Conclusion) 58 (XL) that addresses the position of asylum seekers and refugees, moving away from the country in which they have already found protection in order to seek asylum or find permanent resettlement elsewhere [50]. This EXCOM Conclusion permits the return of individuals to which they have already found protection, which States aim to facilitate through bilateral and multilateral agreements, although it does not define the meaning of protection [47]. Prior to this time, the EXCOM Conclusion No 15 (XXX) has expressed support for a nascent 'safe country of asylum' notion, stating that if a person who requests asylum has a connection or close links with another State, he may, if it appears fair and reasonable, to be called upon first to request asylum from that State [51]. The assumption therefore is that so long as Art 33 of the Refugee Convention is not violated, the State is at liberty to transfer a refugee to a third State but not to avoid its obligations. The issue of avoidance of obligations was noted by the ECtHR when in TI $v U K$ [52], the court observed that a sending State cannot avoid its obligations incurred under the human rights treaties vis-à-vis refugees within territory by engaging in their transfer under the Dublin Convention nor can it 'contract out' its legal obligations. The ECtHR noted:

The Court finds that the indirect removal in this case to an intermediary country, which is also a Contracting State, does not affect the responsibility of the United Kingdom to ensure that the applicant is not, as a result of its decision to expel, exposed to treatment contrary to Article 3 of the Convention. Nor can the United Kingdom rely automatically in that context on the arrangements made in the Dublin Convention concerning the attribution of responsibility between European countries for deciding asylum claims. Where States establish international organisations, or mutatis mutandis international agreements, to pursue co-operation in certain fields of activities, there may be implications for the protection of fundamental rights. It would be incompatible with the purpose and object of the Convention if Contracting States were thereby absolved from their responsibility under the Convention in relation to the field of activity covered by such attribution [52].

This has been re-echoed by the European Parliamentary Resolution 1569 where States were reminded that the transfer of refugees offshore cannot absolve a State from its responsibilities [53]. Therefore, where there is evidence that the asylum seeker or refugee will be subjected to ill treatment on transfer under a third country arrangement and/or agreement, the sending State is prohibited from carrying our such transfers under international law. Foster argues that as much as Article 33 of the Refugee Convention is key in this regard against refoulement (direct), the violations of rights in the third State (indirect refoulement) can be of significance to the analysis of Article 33 [45]. She posits that the conditions of treatment meted out to refugees in the third State (indirect refoulement) in fact amount to persecution in the context of race, religion and nationality viewed not only from a more traditional method of persecution such as violence but in the context of the violation of socio-economic rights [45]. It is her case that a violation of socio-economic rights in the third country may amount to constructive refoulement, if in particular; those conditions were to lead to the serious likelihood of risk in returning home rather than the toleration of harsh conditions [55]. Thirdly, she notes that the reception conditions afforded to refugees in the receiving State may be such as to engage fair and effective asylum procedure, which has a direct connection to refoulement [45].

By and large, the determination of whether a country is safe requires 'anxious scrutiny' [54] and 'rigorous examination'[55] and part of that assessment relates to procedural safeguards which a sending State must take note of in addition to the issue of 'internal flight alternative' and 'internal relocation'. In Januzi v SSHD [56], the concept of internal relocation was engaged where the then House of Lords (now Supreme Court) denied granting refugee status to certain applicants on the 'grounds [that] there is another place, within the country of the appellant's nationality, where he would have no well-founded fear of persecution, where the protection of that country would be available to him, and where in all circumstances he could reasonably and without undue harshness expected to live'. Furthermore, in $A H$ (Sudan) v SSHD [57], the Court held that the assessment of 'internal relocation' required that the conditions in the country of relocation be compared against normal standards of life within the whole country of origin and in doing do so, found that it would be reasonable and not unduly harsh for three non-Arab men from Darfur to relocate to Khartoum.

However, in AMM (Somalia) v SSHD [58], the UK Upper Tribunal in applying the ratio of Strasbourg jurisprudence in Sufi and Elmi $v U K$ found that it "would be unreasonable to return anyone to an Internally Displaced Persons camp in Afgoye Corridor except the person concerned would be able to achieve the life styles of those better-off inhabitants of the Afgoye Corridor settlements'[59]. From the foregoing as distilled from these cases, a return to a safe part of a country of origin is lawful under international law, provided that admission and effective protection can be guaranteed.

On another stretch, Strasbourg jurisprudence has illuminated the horizon in the discussion of safe country notion with its fluctuating decisions hereunder analyzed. It did this by the application of the obligations incumbent on the High Contracting Parties by virtue of Art 1 ECHR charged with securing everyone within its jurisdiction, the rights and freedoms defined in Section 1 of the Convention. In $K . R . S \vee U K$ [60], the applicant Iranian national was facing transfer from the UK to Greece under the Dublin Convention. The applicant presented reports showing that 
Greece in the majority of cases did not meaningfully examine asylum claims by applying 'anxious scrutiny' and 'rigorous examination'. The ECtHR however held that when the matter is not about refoulement but about the conditions under which the asylum claimant is treated in Greece, the appropriate course would be that the applicant be returned to Greece and if unsuccessful, he is at liberty to bring a complaint against Greece, if he so wishes, thereby declining to address the applicant's claim that Greece did not, as a matter of fact, comply with its obligations with regards to procedures established by law [61].

However, in M.S. Sv Belgium and Greece [62] the ECtHR took a different approach to the transfer of a Dublin case, a departure from its position is $K . R . S$ above. In the $M$. $S$. $S$ case, the Court explained prior to the ordering of a Dublin transfer, that the sending State, in the instant case, Belgium, must ensure that Greece is in a position to consider the asylum claim and to apply fairness in all ramifications. The Court reasoned that Belgium knew or ought to have known that the applicant has no guarantee that his application was going to be fairly treated, if so, Belgium was in breach of Article 3 ECHR due to the fact that the applicant was exposed to conditions of detention and living that amounted to degrading treatment by the mere fact that the applicant was returned to Greece. In her analysis of the case, Lambert espoused that Belgium, by knowingly exposing the applicant, to deleterious conditions in Greece, exposed him to conditions tantamount to degrading treatment and it was incumbent on Belgium to have verified how Greece applied their legislation in practice and not simply to assume that $M$. $S$. $S$. would be treated in conformity to ECHR law and EU law. The ECtHR equally found that the extreme urgent procedure adopted by Belgium, which seems to have drastically reduced or obliterated the right of the defense and the examination of the case to a minimum does not meet the requirements of Article $13 \mathrm{ECHR}$ with respect to the right of effective within the meaning of rigorous examination by the competent authority [62].

There is also the responsibility of acts taking place extraterritorially engaging indirect non-refoulement. In Sufi and Elmi $v$ UK [59], the ECtHR had the opportunity of considering the provisions of EU law in its interpretation of Article 3 ECHR within the remit of armed conflict. The Court found that returning anyone to Mogadishu at the time will be violation of Article 3 ECHR as the person or persons will be subjected to degrading treatment due to the general and extreme violence in Mogadishu. Having found Mogadishu unsafe, the Court had to consider whether another part of Somalia would be safe in terms of internal relocation but found the living conditions in main refugee camps in Somalia and even neighbouring Kenya to be extremely dire that it will be unsafe to return anyone there [59].

Similarly, in Hirsi Jamaa and others $v$ Italy [63] another case concerning extraterritoriality principles regarding removal that may lead to exposure of individuals to treatment contrary to Article 3 ECHR, the Court applied the 'knew or should have known' test as discussed in $M . S . S v$ Belgium and Greece and in Sufi and Elmi v UK above. The Court concluded that the bilateral agreement between Libya and Italy cannot be applied to have the potency of absolving Italy from its responsibility under the ECHR. The ECtHR found that Italy knew or should have known that the irregular migrants removed would not be protected in Libya, but it went ahead to remove them in breach of Article 3 ECHR. What appears to be the trend is the use by the ECtHR of its higher threshold of protection standards in applying EU asylum to enhance protection within the 'EU space' that has been applied to situations beyond the EU, driven by the considerations of humanity [64].

Within the EU legal framework proper, the implications of transfer under the Dublin II Regulation was illuminated. In this lead judgment, which will be briefly summarized, concerns the removal of asylum seekers from the United Kingdom and Ireland to Greece under the Dublin II Regulation. The Court of Justice of the European Union (CJEU) in the joined cases of N.S and M.E [65] held that there is now an obligation to examine an asylum application under Article 3 (2) Dublin II Regulation, if the transfer to the Member State which has primary responsibility under Article 3 (1) would expose the asylum seeker to serious risk of violation of fundamental rights as entrenched in the EU Charter of Fundamental Rights. The implication of this judgment is that Dublin II regulation no longer created a presumption that the asylum seekers fundamental rights will be observed by the Member State whose primary responsibility was to determine the application. In her analysis, Gil-Bazo [47], notes that 'the judgment amounts to a reversal of the foundation of the Dublin system, namely the principle of mutual trust among Member States that they are all safe, and in doing so safeguards the dual nature of obligations that Member States have in guaranteeing the rights of individuals when the inter-State agreement fails to deliver on purpose' [64].

The bottom line of what has been discussed in this part is that a State is not excused from its human rights obligations by transferring, returning or removing a migrant to another State on the basis of agreement without actually determining whether there will be violations of the individual's rights under international refugee law or international human rights law. So, the use of the so called safe country cannot exculpate the State from its obligations and whether the receiving state is actually 'safe' must as a minimum be investigated by the sending State applying 'anxious scrutiny' and 'rigorous examination' of the circumstances, avoiding as it should, direct or indirect refoulement.

\section{Medical Cases and Non-refoulement Obligations}

In medical cases, torture or degrading treatment can occur in destination countries. This is because Art 3 ECHR has equally been held to apply to medical cases where expulsion (deportation or removal) would result to harsh suffering for 
an individual due principally to inadequate medical treatment in the destination country. In $D v U K$ [66] the ECtHR had to consider the proposed removal of alien drug courier dying of AIDS to his country of origin, where he was said not to have accommodation, family, moral or financial support and no access to medical treatment. If he were deported to St Kitts, the treatment, which he depended upon, would not be available coupled with the fact that he had no family or relations to support him. The ECtHR held that given the fact that the applicant has entered into the fatal stages of the illness, removal at this stage would hasten his death thereby exposing him to the risk of dying under most distressing circumstances; thus, inhuman treatment $[66,45]$. The focus therefore was ensuring a dignified death rather than prolonging life.

In $N v U K$ [67] the ECtHR nuanced its earlier position in $D$ $v U K$ above where a different decision was reached. $N$ was an AIDS sufferer from Uganda, resident in the United Kingdom for over five years, having been stabilized with medication, which would not be available in Uganda upon removal. The ECtHR held that Art 3 only usually applied to intentional acts or omission of a state or non-state body insisting that in medical cases, Art 3 applies only in very exceptional circumstances; therefore Art 3 is not meant to be used to address the disparity in medical care between the Contracting States and the applicant's state of origin [67]. The implication is that $N$ has established a high threshold that applicants will cross in determining whether Art 3 is engaged in medical cases where removal had been proposed [68].

The idea is that the deportation of a person to a country where there is a risk that they will suffer, torture, and cruel, inhuman and degrading treatment is prohibited and the State in breach will be held responsible. But the implied nonrefoulement prohibitions especially under the ECHR are certainly unclear and highly contentious, which has not provided the necessary panacea against deportation and/or removal, only acting to an extent, as a check. Arguing vehemently, Greenman stated that 'there is something problematic about the way the prohibitions on refoulement are read into human rights provisions using the 'removal plus risk' formulation that can be seen in the medical cases with unfortunate consequences and detriment for individual protection, submitting that non-refoulement under the ECHR is a castle built on sand' [69]. Therefore, in the medical cases under Article 3 ECHR $[66,67]$, the underlying issue is that if the deportee would be exposed to torture or ill treatment in the destination state, deportation would be unlawful. In deciding $D v U K$, the ECtHR stated:

The Court must reserve to itself sufficient flexibility to address the application of that Article [Art 3] in other contexts, which might arise. It is therefore not prevented from scrutinizing an applicant's claim under Article 3 where the source of risk of proscribed treatment in the receiving country stems from factors which cannot engage directly the responsibility of the public authorities of that country, or which, taken alone, do not in themselves infringe the standards of that Article. To limit the application of Art 3 in this manner would be to undermine the absolute character of its protection [66].

In reaching this judgement, the ECtHR emphasized the absolute nature of $D v U K$ that the Grand Chamber had the opportunity to reconsider in $N v U K$, the ECtHR stated:

'The decision to remove an alien who is suffering from a serious mental or physical illness to a country where facilities for the treatment of that illness are inferior to those available in the Contracting State may raise an issue under Article 3, but only in a very exceptional case where the humanitarian grounds against the removal are compelling' [67].

The Court explicitly aimed to strike a fair balance between the demands of the general interest of the community and the requirements of the protection of the individual's fundamental rights without placing an obligation for the provision of free and unlimited health care to all irregular aliens.

In short, the significance and/or ratio from the medical cases may be interpreted to mean that if there are substantial grounds for believing that the deportee would face a real risk of harm in the destination country, emanating from circumstances giving rise to responsibilities of the Destination State, the expelling State is under a nonrefoulement obligation. But if otherwise, the expelling State can only be under an obligation of non-refoulement if the deportee can show exceptional circumstances in addition to economic considerations. As Greenman pointed out, 'in reshaping non-refoulement in the medical cases, the ECtHR is undermining the absolute nature of Art $3 \mathrm{ECHR}$ and the indivisibility of civil and political and socio-economic rights'[69] with the unfortunate creation of uncertainty due to the Court's inconsistency leaving deportees helpless, without knowing on what side the pendulum will swing.

Interestingly, recent legal developments in medical cases have thrown up arguments regarding the absolute nature of Art 3 ECHR as it concerns non-refoulement. One of those was the case of Abdida [70] decided by the CJEU in December 2014. Abdida [70] has enthroned the use of health cases against removal-non refoulement obligations and has gone ahead to apply suspensive effect of returns in health cases. The facts are that Mr. Moussa Abdida, a Nigerian national was an irregular migrant residing in Belgium who submitted an application to the Belgian state requesting leave to remain on medical grounds- he was diagnosed with AIDS. This was refused and he was asked to leave the country and whilst appealing against the decision to remove him, Mr. Abdida was not allowed an in-country right of appeal, which means the decision has no suspensive effect. Furthermore, Mr. Abdida's basic social security and medical care were withdrawn. In the legal proceedings that ensured at the Belgium domestic courts, which finally reached the Brussels Employment Court regarding Abdida's entitlement under EU law, the issue was what sort of judicial remedies, (suspensive or otherwise) and social rights should be available to a thirdcountry irregular immigrant when he claims to remain in the country to receive medical treatment. The Belgian court held that under Belgian law, Mr. Abdida had no judicial remedy 
with suspensive effect in refusing permission to remain in Belgium and that he was not entitled to any form of social assistance other than emergency medical assistance.

Nonetheless, the Belgian court referred two questions to the CJEU. The questions were whether Mr. Abdida under EU law should have a suspensive effect remedy regarding the removal decision and whether he should receive basic social assistance other than the emergency medical care pending his appeal. Impressively, the CJEU answered yes to both questions holding that such an immigrant must be able to challenge the decision to send him back to his country of origin with suspensive effect and must also, in the meantime, get social assistance to cover his basic needs pending his appeal. The CJEU applied the Return Directive, supra, in addition, referred to Art 47 of the Charter in reaffirming the principle of effective judicial protection [71]. In further applying the Charter, the Court also noted that Article 19 (2) of the Charter states, inter alia, that no one may be removed to a State where there is a serious risk that he or she would be subjected to inhuman or degrading treatment. This shows that the CJEU is willing to interpret the provisions of EU law in such a way that they comply with the Charter of Fundamental Rights and with the ECHR.

Furthermore, in accordance with Art 52 (3) of the Charter, the CJEU pointed out that the case-law of the ECtHR must be taken into account in interpreting EU law with respect to human rights [72]. And in doing so, the CJEU commented on the authority of $N v U K$ [67] where the Court explained that, while non-nationals subject to a decision authorizing their removal cannot, in principle, claim any entitlement to remain in the territory of a State in order to continue to benefit from medical, social or other forms of assistance and services provided by that State, a decision to remove a foreign national suffering from a serious physical or mental illness to a country where the facilities for the treatment of the illness are inferior to those available in that State may raise an issue under Article 3 ECHR in very exceptional cases, where the humanitarian grounds against removal are compelling. The CJEU [70] emphasized that those very exceptional cases are characterized by the seriousness and irreparable nature of the harm that may be caused by the removal of a third country national to a country in which there is a serious risk that he will be subjected to inhuman or degrading treatment. Therefore, in order for the appeal to be effective in respect of a return decision whose enforcement may expose the third country national concerned to a serious risk of grave and irreversible deterioration in his state of health, that third country national must be able to avail himself, in such circumstances, of a remedy with suspensive effect. This is to ensure that a competent authority has examined the matter before a return decision is enforced in compliance with Art 19 (2) of the Charter [73].

Following this authority, it is now clear that the CJEU has firmly established the standard that Member States are required to follow in providing for the basic needs of a third country national suffering from a serious illness who has appealed against a return decision and whose enforcement may expose him to a serious risk of grave and irreversible deterioration in his state of health. This decision in essence reignites the argument of exceptionality decided by the ECtHR in the case of $N v U K$, supra but the CJEU in the Abdida case took a purposive and pragmatic position in its ebullient pronouncement.

It might be that given the CJEU's position in Abdida, the ECtHR has now seized an opportunity in the very recent case of Paposhvili v Belgium [74] decided on the 13 December 2016 to remove the exceptionality threshold in medical cases concerning third country nationals which softens the unduly restrictive approach that had so far been followed in cases concerning the expulsion of seriously ill migrants. The facts are that Mr. Paposhvili, a Georgian national living in Belgium, was seriously ill and claimed that his expulsion to Georgia would put him at risk of inhuman treatment and an earlier death due to the withdrawal of the treatment he had been receiving in Belgium. Unfortunately, he died in June 2016 in Belgium whilst the case was pending before the Grand Chamber. The ECtHR did not strike his application out of the list but in reliance on its case management powers proceeded to give a very important and spectacular judgment affecting third country nationals with medical cases whilst facing expulsion. The Court held that there would have been a violation of Article 3 if Belgium had expelled $\mathrm{Mr}$. Paposhvili to Georgia without having assessed the risk faced by him in the light of the information concerning his state of health and the existence of appropriate treatment in Georgia. The ECtHR [74] equally found that there would have been a similar violation of Article 8 if Belgium had expelled him without having assessed the impact of his return on his right to respect for his family life in view of his state of health.

Paposhvili thus comes to fill what Judge Lemmens in his concurring opinion calls a 'gap in the protection against inhuman treatment' in so doing included as exceptional more than just cases of imminent death that now appears to open up what in practice has resulted in a limited application of the high threshold. The Grand Chamber equally seized the occasion to meticulously set out a range of procedural duties for the domestic authorities in the ECHR state parties solely aimed at a more rigorous assessment of the risk as required by the absolute nature of the Article 3 ECHR prohibition. The Court emphasized that in assessing the alleged risk of ill treatment; the domestic authorities should verify whether the care available in the receiving state is 'sufficient and appropriate in practice for the treatment of the applicant's illness so as to prevent him or her being exposed to treatment contrary to Article 3'. The ECtHR [74] reiterated that domestic authorities should also consider 'the extent to which the individual in question will actually have access to this care and these facilities in the receiving State such as cost of medication and treatment, the existence of a social and family network, and the distance to be travelled in order to have access to the required care'.

The ECtHR further took a proactive approach in requiring that the returning State must obtain individual and sufficient assurances from the receiving State, as a precondition for 
removal, in addition to ensuring that appropriate treatment will be available and accessible to the persons concerned so that they do not find themselves in a situation contrary to Article 3 which appears to be a nascent approach by the Court to move its corpus of case law principles closer to its principles on the absolute nature of the Article 3 prohibition [83]. From the ratio of the above cases, it can now be seen that the 'swinging pendulum' of medical cases involving third country nationals facing expulsion is gradually been narrowed to reflect clear rationality and practicality. This approach by the CJEU in Abdida and the ECtHR in Paposhvili now attacks the high threshold required of medical cases to a purposive, reasonable, and humane level [70, 74].

However, on 6th February 2018, the Court of Appeal in $A M$ (Zimbabwe) v SSHD [75] gave authoritative guidance on how the case of Paposhvili v Belgium should be applied by English courts. The issue in $A M$ (Zimbabwe) concerned the applicable test for when removal of seriously ill people to their country of origin would raise an issue under Article 3 of the ECHR as it concerns medical cases. Sales LJ, giving the judgment of the Court of Appeal, decided that removal would only violate Article 3 if intense suffering or death would be imminent in the receiving state as a result of the nonavailability of treatment which would have been available in the UK. The matter went forth to the Supreme Court and on the 04 December - 05 December 2019, the Supreme Court heard the appeal in $A M$ (Zimbabwe) and the key issue was whether the Supreme Court should depart from the House of Lords decision in $N v U K$ discussed above. In essence, the Supreme Court was asked to consider whether to return AM to Zimbabwe would violate his right under Article 3 of the European Convention on Human Rights not to be subjected to inhuman treatment by reason of his medical condition, in light of the decision in Paposhvili $v$ Belgium. While it appears the Court of Appeal has reduced the potency of Paposhvili $v$ Belgium as it concerns non-refoulement in medical cases, it remains to be seen what the Supreme Court will decide and the effect of the decision on non-nationals with medical conditions facing expulsion.

\section{Torture in the Destination Country}

The prohibition against torture in the destination country raises the question as to whether there is a real risk of exposure to ill treatment to the proposed destination. Where the applicant has been removed, the existence of the risk must be assessed with reference to fact that the deporting State ought to know. As the ECtHR stated in Cruz Varas [76] 'the Court is not precluded from having regard to information which comes to light subsequent to the expulsion'. In Soering $v$ United Kingdom [38] the court had to consider torture in the country of destination. The applicant German national was accused of killing his girlfriend's parents in Virginia the United States (US) and was arrested in the United Kingdom. The US sought his extradition to the US where the death penalty could be imposed after conviction. In addition, he could be subject to the death row phenomenon where prisoners spend up to six and eight years on the death row prior to execution. Soering claimed he could face death penalty and the death row phenomenon if extradited, and the court agreed that the death row could amount to inhuman treatment, which will violate Art 3 ECHR [87]. The issue being that the applicant having fled the US for the UK was in the jurisdiction of the UK, but the treatment if carried out will be done in the US by the US authorities. The UK argued that the Convention should not be interpreted as to impose responsibility on a Contracting State for acts, which occur outside its jurisdiction [38]. The court disagreed and emphasized that a Contracting State incur liability for actions taken by it that has consequences of exposing an individual to the proscribed ill treatment, therefore the nexus or crucial link has been established. Furthermore, 'extradition in such circumstances would, according to the Court, 'plainly be contrary to the spirit and intendment of the Article' and would 'hardly be protection against expulsion under Art 3 ECHR compatible with the underlying values of the Convention' [38].

Similarly, in Mubilanzila Mayeka and Kaniki Mitunga $v$ Belgium [77], the ECtHR found that the applicant's subsequent deportation to a destination country after her detention at the host country (as above) was unlawful. The court specifically held that the Belgian authorities' decision to deport the applicant without the provision of adequate preparation, supervision and safeguards at the destination country was unlawful. However, in Vilvarajah and Others $v$ $U K$ [78] the applicants' asylum seekers were deported from the UK but there were undisputed evidence that they will be ill-treated in Sri-Lanka but the ECtHR nevertheless did not find a violation of Art 3 ECHR reasoning that the UK could not have foreseen without convincing evidence that they would be ill-treated as they claimed.

\section{Conclusion}

This paper has shown that there is overwhelming evidence pointing to the establishment of non-refoulement as a norm of customary international law with wide acceptance by the international community of the prohibition of torture and cruel, inhuman and degrading treatment, as jus cogens.

The concept of safe third country, it has been submitted, raises crucial issues of state responsibility regarding the fulfilment of all obligations under the regime of both international refugee law and human rights law with respect to the exercise of jurisdiction. This is because a sending State cannot avoid its obligations incurred under the human rights treaties vis-à-vis refugees within territory by engaging in their transfer under the Dublin Convention nor can it 'contract out' its legal obligations.

Furthermore, the determination of whether a country is safe requires 'anxious scrutiny' and 'rigorous examination' and such assessment relates to procedural safeguards which a sending State must take note of in addition to the issue of 'internal flight alternative' and 'internal relocation'. The bottom line is that a State is not excused from its human 
rights obligations by transferring, returning or removing a migrant to another State on the basis of agreement without actually determining whether there will be violations of the individual's rights under international refugee law or international human rights law.

In the medical cases, the requirement that the returning State must obtain individual and sufficient assurances from the receiving State, as a precondition for removal, in addition to ensuring that appropriate treatment will be available and accessible to the persons concerned so that they do not find themselves in a situation contrary to Article 3 is a welcome development. This narrows the uncertainty and inconsistency of judicial pronouncements in this area and reduces drastically the swinging pendulum in medical cases. This nascent approach by the ECtHR and CJEU to move its corpus of case law principles closer to its principles on the absolute nature of the Article 3 prohibition radiates practicality and halts the vanishing relevance of nonrefoulement. This high threshold in $N$ has now been reduced to a purposive, reasonable, and humane level- a Daniel has come to judgment. The combined effect of the decision in Abdida by the CJEU and the ECtHR in Paposhvili is that the high threshold established by the case of $N$ for the successful reliance by migrants against removal is now weakened. However, it is not yet over as we await the Supreme Court's decision in AM Zimbabwe.

\section{References}

[1] Abdulaziz, Cabales and Balkandani v UK (1985) 7 EHRR 471, para 67.

[2] Seyla Benhabib, 'Borders, Boundaries and Citizenship' (2005) 38 (4) Political Science and Politics 673, 675.

[3] Matthew Gibney and Randall Hansen, 'Deportation and the liberal state: the forcible return of asylum seekers and unlawful migrants in Canada, Germany and the United Kingdom' New Issues in Refugee Research Working Paper No. $77<$ http://www.unhcr.org/3e59de764.pdf > accessed 14 August 2015.

[4] Jane McAdam, Complementary Protection in International Refugee Law (OUP 2007) 9; see also Elihu Lauterpacht and Daniel Bethlehem, The scope and content of the principle of non-refoulement: Opinion in Erika Feller and Volker Türk and Frances Nicholson (eds) Refugee Protection in International Law: UNHCR's Global Consultations on International Protection (CUP 2003) 148-153; See also HRC, CCPR General Comment No 24 (2 Nov 1994) CCPR/C/21/ Rev. 1/Add. 6 para 8, cf Art 7 ICCPR with Art 3 CAT above alongside Art 33 of the 1951 Convention Relating to the Status of Refugees 189 UNTS 150.

[5] Convention against Torture and Other Cruel, Inhuman or Degrading Treatment or Punishment (adopted 10 December 1984, entered into force 26 June 1987) 1465 UNTS 85 (CAT) Art 3 CAT.

[6] R v Bow Street Metropolitan Stipendiary Magistrate ex p Pinochet Ugarte (No 3) [1999] 2 WLR 827; [2000] 1 AC 147 [Lord Browne-Wilkinson].
[7] Tamas Molnar, 'The principle of non-refoulement under international law: Its inception and evolution in a nutshell' (2016) 1 (1) Courvinus Journal of International Affairs 51, 51.

[8] Feraud-Giraud et Ludwig von Bar, (Rapporteurs) Regles internationals sur l'admission et l'expulsion des strangers (Institut de Droit international Session de Geneve, 1892).

[9] See the Convention Relating to the Status of Refugees 2545 189 UNTS 150 (entered into force 22 April 1954).

[10] See also the 1984 United Nations Convention Against Torture (CAT), Article 3.

[11] See Aoife Duffy, 'Expulsion to Face Torture? Nonrefoulement in International Law' (2008) 20 International Journal of Refugee Law 374, 383 citing 'Extraditions, Expulsions, Deportations' in, Anti-terrorism Measures, Security and Human Rights - Developments in Europe, Central Asia and North America in the Aftermath of September 11 (The International Helsinki Federation, 2003).

[12] UNHCR, UNHCR Note on the Principle of NonRefoulement $<$ http://www.refworld.org/docid/438c6d972.html >accessed 08 February 2017, see also UNHCR, Advisory Opinion on the Extraterritorial Application of NonRefoulement Obligations under the 1951 Convention relating to the Status of Refugees and its 1967 Protocol<http://www.refworld.org/pdfid/45f17a1a4.pdf >acce ssed 08/02/2017.

[13] Vienna Convention on the Law of Treaties (adopted 23 May 1969) 1155 UNTS 331 (VCLT), Art 53 provides 'A treaty is void if, at the time of its conclusion, it conflicts with a peremptory norm of general international law. For the purposes of the present Convention, a peremptory norm of general international law is a norm accepted and recognized by the international.

[14] Jean Allain, 'The jus cogens Nature of non-refoulement' (2002) 13 International Journal of Refugee Law 533, 535.

[15] UNHCR, EXCOM Conclusion No 82 (XL) (1989).

[16] Cathryn Costello and Michelle Foster, 'Non Refoulement as Custom and Jus Cogens? Putting the Prohibition to the Test' (2015) Netherlands Yearbook of International Law 46, 307.

[17] A Orakhelashvili, Peremptory norms in international law (OUP 2006) 56; see the UNHCR, EXCOM Conclusion No 25 (XXXIII) 'General Conclusion on International Protection General Conclusion on International Protection' (1982).

[18] Alice Farmer, 'Non-Refoulement and Jus Cogens: Limiting Anti-Terror Measures That Threaten Refugee Protection' (2008) 23 (1) Georgetown Immigration Law Journal 1, 8.

[19] Organization of American States, Cartagena Declaration on Refugees OAS Ser L/V/II. 66 Doc 10 Rev 1 at III (5) (1984).

[20] Organization for African Unity Convention Governing the Specific Aspects of Refugee Problems in Africa (adopted 10 September 1969, entered into force June 20 1974) 1001 UNTS 45 .

[21] Brazil Declaration and plan of action 'A Framework for Cooperation and Regional Solidarity to Strengthen the International Protection of Refugees, Displaced and Stateless Persons in Latin America and the Caribbean' (3 December 2014) <http://www.refworld.org/docid/5487065b4.html > accessed 09 February 2017. 
[22] See the analysis of this Hirsi Jamaa and Others v Italy case, by Mariagiulia Guiffre, 'Watered-Down Rights on the High Seas: Hirsi Jamaa and Others v Italy’ (2012) 61 (3) International \& Comparative Law Quarterly 728, 733

[23] $\mathrm{K}$ Wouters, International legal standards for the protection from refoulement (Intersentia 2009) 30.

[24] UNGA Res 51/75 (12 February 1997) cited by Castello and Foster.

[25] E Lauterpacht and D Bethlehem, 'The scope and content of the principle of non-refoulement' in Feller E, Volker T and Nicholson F (eds) Refugee protection in international law: UNHCR's global consultations on international protection (CUP 2003) 93.

[26] Julian M Lehman, 'Rights at the Frontier: Border Control and Human Rights Protection of Irregular International Migrants' (2011) 3 (2) Goettingen Journal of International Law 733, 750

[27] Gerald L. Neuman, 'Extraterritorial Violations of Human Rights by the United States' (1994) 9 (4) American University International Law Review 213, 25; see also Jean Allain, 'The Jus Cogens Nature of Non-Refoulement', (2001) 13 (4) International Journal of Refugee Law 533, 534 citing Saadi v Italy (2009) 49 EHRR 30.

[28] Saadi v Italy (2009) 49 EHRR 30.

[29] A v Netherlands App no 4900/06 (ECtHR, 20 July 2010) 142.

[30] N v Sweden App no 23505/09 (ECtHR, 20 July 2010) paras 51-54.

[31] CAT, Consideration of Reports Submitted by States Parties Under Article 19 of the Convention: Comments by the Government of the United Kingdom of Great Britain and Northern Ireland to the conclusions and recommendations of the Committee against Torture (8 June 2006) UN Doc $\mathrm{CAT} / \mathrm{C} / \mathrm{GBR} / \mathrm{CO} / 4 /$ Add. 1 para 48 .

[32] International Covenant on Civil and Political Rights (adopted 16 December 1966, entered into force 23 March 1976) 999 UNTS 171 (ICCPR) Art 7.

[33] A. R. J v Australia, Communication No 692/1996 UN Doc CCPR/C/60/D/692/1996 (11 August 1997) Annex, para 6.9; see also HRC, CCPR Considerations on Reports Submitted by States Parties Under Article 40 of the Covenant: Concluding observations of the Human Rights Committee-United Kingdom and Northern Ireland (30 July 2008) UN Doc $\mathrm{CCPR} / \mathrm{C} / \mathrm{GBR} / \mathrm{CO} / 6$ para 12 .

[34] Ian MacDonald and Ronan Toal, MacDonald's Immigration Law \& Practice (1st Supp, 7th edn, LexisNexis 2009) 95; see Ireland v United Kingdom (1978) 2 EHRR 25, para 96.

[35] Tyrer v UK (1978) 2 EHRR 1, para 35, see also Campbell and Cosans v UK (1982) 4 EHRR 293, para 28-30; Soering v UK (1989) 11 EHRR 439, para 100.

[36] Katharina Rohl, 'Fleeing violence and poverty: nonrefoulement obligations under the European Convention of Human Rights' (2005) UNHCR Working Paper no 111, 31 $<$ http://www.refworld.org/pdfid/4ff169d92.pdf >accessed 03 September 2014.

[37] Chahal v UK (1996) 23 EHRR 413, para 79.

[38] Soering v UK (1989) 11 EHRR 439.
[39] Nuala Mole, Asylum and the European Convention on Human Rights (Council of Europe Publishing 2007) 30.

[40] Stephan Breitenmoser and Gunter E Wilms, 'Human Rights v. Extradition: The Soering Case' (1989/90) 11 Mich. J. Int'L L 843, 885-886; Terje Enarsen, 'The European Convention on Human Rights and die Notion of an Implied Right to de facto Asylum', (1990) 2 International Journal of Refugee Law 361, 366; William A Schabas, 'International Law and the Abolition of the Death Penalty’ (1998) 55 WASH. \& LEE L. REV. 797, 803.

[41] Hemme Battjes, 'The Soering reshold: Why Only Fundamental Values Prohibit Refoulement in ECHR Case Law' (2009) 11 (3) European Journal of Migration and Law 205; see also Nuala Mole, Asylum and the European Convention on Human Rights (Council of Europe Publishing 2007) 30; see para $79-81$ of Chahal where the ECtHR made reference to para 88 of the Soering case.

[42] Christine Van Den Wyngaert,'Applying the European Convention on Human Rights to Extradition: Opening Pandora's Box?' (1990) 39 ICLQ 757, 760-761; Richard B Lillich, The Soering Case' (1991) 85 AM. J. INT'L L 128, 145-149; Collin Warbrick, 'Coherence and the European Court of Human Rights' (1989/90) 11 Mich. J. Int'L L 1073, 1079.

[43] G. S Goodwin-Gill and J McAdam, The Refugee in International Law (OUP 2010) 392.

[44] Michelle Foster, 'Protection Elsewhere: The Legal Implications of Requiring Refugees to Seek Protection in Another State' (2007) 28 (2) Michigan Journal of International Law 223, 224.

[45] Michelle Foster, 'Responsibility Sharing or Shifting? "Safe" Third Countries and International Law' (2008) 25 (2) Refuge 64, 64.

[46] Alberto Acherman and Mario Gattiker, 'Safe Third Countries: European Developments' (1995) 7 (1) International Journal of Refugee Law 19; see also K Hailbronner, 'The Concept of "Safe Country" and Expeditious Asylum Procedures: A Western European Perspective' (1993) 5 International Journal of Refugee Law 36.

[47] M T Gil-Bazo, 'The Safe Third Country Concept in International Agreements on Refugee Protection: Assessing State Practice' (2015) 33 (1) Netherlands Quarterly of Human Rights 42, $<$ http://eprint.ncl.ac.uk/file_store/production/208565/36C34AD6D85F-4359-8A2B-45C466C52A03.pdf $>3$, accessed 11 February 2017, citing Regulation (EU) No 604/2013 of the European Parliament and of the Council of 26 June 2013 establishing the criteria and mechanisms for determining the Member State responsible for examining an application for international protection lodged in one of the Member States by a third-country national or stateless person [2013] OJ L 180/31 (Dublin III).

[48] Rosemary Byrne and Andrew Shacknove, 'The Safe Country Notion in European Asylum Law' (1996) 9 Harvard Human Rights Journal 185, 192.

[49] See First List of Safe Countries (Refugee Convention and Human Rights (1)) of the 2004 Act mentioned above, see also Gina Clayton, Immigration and Asylum Law, (5th ed OUP, 2012) 439.

[50] UNHCR, EXCOM Conclusion No 58 (XL) 'Problem of Refugees and Asylum-Seekers Who Move in an Irregular Manner from a Country in Which They Had Already Found Protection' (1989). 
[51] UNHCR, EXCOM Conclusion No 15 (XXX) 'Refugees Without An Asylum Country' (1979) para h (iv).

[52] TI v UK App No 43844/98 (ECtHR, 7 March 2000) para 456457.

[53] Council of Europe Parliamentary Assembly, Resolution 1569 (2007) on Assessment of Transit and Processing Centres as a Response to Mixed Flows of Migrants and Asylum Seekers (01 October 2007) para 13.6.

[54] See R (Yogathas) v SSHD [2003] AC 920.

[55] Nasseri v SSHD [2008] EWCA 464.

[56] Januzi v SSHD [2006] UKHL 5.

[57] AH (Sudan) v SSHD [2008] EWCA Civ 579.

[58] AMM (Somalia) v SSHD [2011] UKUT 00445 (IAC) [501].

[59] Sufi and Elmi v UK App No 8319/07 and 11449/07 (ECtHR, 28 June 2011).

[60] K. R. S v UK App No 32733/08 (ECtHR, 02 December 2008).

[61] See for instance the Directive 2013/33/EU of the European Parliament and of the Council of 26 June 2013 laying down standards for the reception of applicants for international protection (recast) [2013] OJ L 180/96; Directive 2013/32/EU of the European Parliament and of the Council of 26 June 2013 on common procedures for granting and withdrawing international protection (recast) [2013] OJ L 180/60.

[62] M. S. S v Belgium and Greece App No 30696/09 (ECtHR, 21 January 2011) paras 342, 358-359.

[63] Hirsi Jamaa and Others v Italy App No 27765/09 (ECtHR, 23 February 2012).

[64] Helen Lambert, 'Safe Third Country' in the European Union: An Evolving Concept in International Law and Implications for the UK' (2012) 26 (4) Journal of Immigration and Asylum Law 318; Helen Lambert, 'Safe Third Country' in the European Union: An Evolving Concept in International Law and Implications for the UK' (2012) University of Westminster School of Law Research Paper 13/05<http://www.academia.edu/2447287/Safe_Third_Countr $\mathrm{y}$ in the European Union An Evolving Concept in Intern ational_Law_and_Implications_for_the_UK $>11$ accessed 10 February $20 \overline{17}$.

[65] Joined Cases C-411/10 and C-493/10 N. S. v Secretary of
State for the Home Department \& M. E. and Others v Refugee Applications Commissioner [2011] ECR I-13905.

[66] In D v UK (1997) 24 EHRR 423.

[67] N v UK (2008) 47 EHRR 885.

[68] cf Bensaid v UK (2001) 33 EHRR 10, paras 36-40, see also CA v SSHD [2004] EWCA Civ 1165.

[69] Kathryn Greenman, 'A Caste Built on Sand? Article 3 ECHR and the Source of Risk in Non-Refoulement Obligations in International Law' (2015) 00 (00) International Journal of Refugee Law 1, 2.

[70] Case C-562/13 Abdida [2014] (18 December 2014).

[71] See the Charter of Fundamental Rights of the European Union [2000] OJ C 364/1, Art 47; see also judgments in Case C432/05 Unibet (London) Ltd and Unibet (International) Ltd v Justitiekanslern [2007] ECR 1-2271, para 37, and Case C-93/12 Agrokonsulting-04-Velko Stoyanov [2013] ECR para 59.

[72] Art 52 (3) of the EU Charter states: 'In so far as this Charter contains rights which correspond to rights guaranteed by the Convention for the Protection of Human Rights and Fundamental Freedoms, the meaning and scope of those rights shall be the same as those laid down by the said Convention. This provision shall not prevent Union law providing more extensive protection'.

[73] See discussions on this at EU Litigation $<$ https://eulitigationblog.com/2015/03/01/case-c-56213-moussaabdida-return-of-illegal-immigrants-and-proper-judicialremedy-with-suspensive-effect/ > accessed 29 March 2017, see also EDAL-European Database of Asylum Law, CJEU: Advocate General Opinion in Case C-562/13 Abdida $<\mathrm{http}$ ://www.asylumlawdatabase.eu/en/content/cjeu-advocategeneral-opinion-case-c-56213-abdida> accessed 29 March 2017.

[74] Paposhvili v Belgium App no 41738/10 (ECtHR, 13 December 2016), see para 133, 222-226 of the judgment.

[75] AM (Zimbabwe) v SSHD [2018] EWCA Civ 64.

[76] Cruz Varas v Sweden App no 15576/89 (ECtHR 20 March 1991) para 76.

[77] Mubilanzila Mayeka and Kaniki Mitunga v Belgium App no 13178/03 (ECtHR, 12 October 2006) paras 8-10.

[78] Vilvarajah and Others v UK App no 13163/87 (ECtHR, 30 October 1991). 